DOI: http://dx.doi.org/10.4314/ljh.v26i1.2

\title{
Language of Power: Pidgin in the Colonial Governance of Northern Nigeria
}

\author{
Philip Atsu Afeadie \\ Lecturer, Department of History \\ University of Ghana, Legon
}

\begin{abstract}
Pidgin was indispensable as a working language of colonial governance in Northern Nigeria, epitome of the distinct and continuing role of pidgin as a language of the workplace in West Africa. The study is largely based on archival materials and oral interviews of some former African employees. Notably, British colonial authorities adopted pidgin as a language of government in Northern Nigeria, as they lacked a wider medium for inter-ethnic communication. African political agents were employed as intermediaries, based on their knowledge of pidgin and other local languages, enabling them bridge communication between government and chiefs. And pidgin was hard to replace.
\end{abstract}

Keywords: intermediaries, pidgin, colonial administration, Northern Nigeria, evolution

Pidgin is English modified by another language or multiple other languages. In the evolution of pidgin, the original English is termed the superstrate language, denoting the language of the influential people, and the non-English language known as the substrate language. Accordingly, English would be the superstrate language in West Africa, as the beginnings of pidgin were associated with English traders regarded as the influential group relative to Africans, in terms of technological prowess and their capacity as employers. Over time, however, the grammatical innovations introduced in pidgin from various languages of West Africa would diminish the intelligibility of pidgin to Anglophone European officials.

In West Africa, Mafeni (1971) notes that pidgin essentially constitutes a language group composed of varied dialects of pidgin and related creole forms (nativised pidgin), with a creole serving as pidgin outside its spoken area of mother tongue (pp.95-96). Thus pidgin prevails throughout West Africa, particularly the coastal cities and towns of Anglophone countries. As the language group differs in grammatical system, however, the regional varieties are less mutually intelligible. 
This paper examines the role of pidgin as a working language of colonial government in Northern Nigeria. Of its organisation, the paper provides background information, including the functions of pidgin in the pre-colonial period. Then, the paper examines pidgin at the workplace of British colonial administration in Northern Nigeria, exploring the themes of English language requirement in colonial rule; tasks of governance performed by African service assistants who spoke pidgin; political influence associated with the tasks of governance; and government efforts to control the power of African service assistants. The concluding theme explores the functions of pidgin in Nigeria today.

\section{Early Pidgin English in West Africa}

Pidgin in Nigeria developed largely out of the Krio language of Sierra Leone ${ }^{1}$, and partly from other local English-based jargons on the coast, which had emerged by the late $17^{\text {th }}$ century out of a Portuguese trade jargon in existence during the previous century (Mafeni, 1971, p.97; Huber, 1999, pp.44, 128).

Among its early functions, pidgin served primarily as a language of trade, a medium of inter-ethnic communication between Africans and European traders, particularly English traders. Similarly, European officials on board ships largely communicated through pidgin with their fort slaves who could not speak any form of English (Huber, 1999, p.54). In association with pidgin as a language of trade, there emerged a distinct group of Africans serving as mediators or brokers between the European traders and Africans. These intermediaries included 'gold takers' who adjudicated trade disputes between Africans and European officials. According to Dantzig (1999), the intermediaries also involved linguists or 'interpreters' who were largely drawn from local chiefs and related political officials, synonymous with the tradition of skyeame among local societies on the Gold Coast and elsewhere in West Africa (p.84).

By the second half of the $19^{\text {th }}$ century, pidgin had assumed the status of a language of social communication, becoming a lingua franca and functioning as a third-party means of communication between differing indigenous language groups on the West African coast (Huber, 1999, p.116)

1 According to Huber (1999), Krio itself derives from the New World creole languages involving either one or a combination of three scenarios: Gullah, creolised English of the slave plantations of Carolina and others of the southern states of USA, as spoken by Nova Scotians who were shipped to Sierra Leone; and the Jamaican English-based creole of the Maroons (escaped slaves) who also settled in Sierra Leone; and the language of soldiers of the $4^{\text {th }}$ West India Regiment, discharged from their headquarters in April 1819 and settled in Sierra Leone (pp.62-63). 
In the era of European colonisation of Africa from the last quarter of the $19^{\text {th }}$ century through the first half of the $20^{\text {th }}$ century, pidgin would develop on its role of transaction between Africans and Europeans, becoming institutionalised as a medium of communication in the governance of British colonial establishment in Northern Nigeria.

\section{English Language Requirement in Colonial Rule}

In July 1886, British colonial rule began in Northern Nigeria with the chartering of the Royal Niger Company, a British trading enterprise which had been operating in the region, and thence assumed authority to administer the region on behalf of the British government. As a trading concern, the major objective of the Royal Niger Company always involved securing the cooperation of the traditional rulers of Northern Nigeria in ensuring peaceful conditions for trade (Mockler-Ferryman, 1892, pp.254-255; Fremantle, 1925, p.5).

Now equipped with a charter, the Company chose to administer the region through the traditional rulers and their political institutions. But the Company officials could not conduct effective relations with the traditional rulers because they lacked knowledge of local conditions and languages. Company officials could therefore not collect adequate information to develop effective administration for their dominion. They needed brokers or assistants who possessed knowledge of the local conditions as well as English, and who could communicate between the Company and the indigenous people. Thus, Company officials elevated some of the local people to the position of political agents, the term denoting distinguished messenger-interpreters. As intermediaries, political agents assisted government diplomacy and helped to establish and maintain relations between the Company and the traditional rulers, reminiscent of Africans who served as brokers between European traders and African merchants during the pre-colonial period. Political agents also gathered information that was needed for policy-making in administration, while some served as District Agents and administered Company stations.

Agents were recruited on the basis of their qualifications, the most important of which was linguistic competency, essentially involving fluency in pidgin together with proficiency in some indigenous language, such as Hausa, Yoruba or Nupe. In the prevailing conditions of limited Standard English available to Africans, Company officials adopted pidgin as a language of government in their territory. For the Company officials, many of whom could not speak any local language, pidgin was a suitable medium of communication with the indigenous people. Political agents were fluent in pidgin, in addition to their native tongues. Accordingly, they were suitable as intermediaries between the people and the Company officials. On the one hand, they could communicate in indigenous languages with the people. On the other hand, they could speak with the Company officials, many of whom had acquired pidgin. For instance, John Flint (1960) notes that when the town of Kabba was conquered during the Niger Sudan Campaign of 1897, George Goldie, the governor of the 
Company territories, addressed the people 'in the most inimitable pigeon English (which was then translated by interpreters into Yoruba and Nupe)' [p. 250]. Perham and Bull (1963) also observe that the would-be high commissioner, Lugard, could as well pick out some pidgin (p.148).

During the 1890s, Company administration was progressively superseded by a new imperialism that would require even more political agents and the entrenchment of pidgin in the governance of Northern Nigeria. After 1895, British colonial policy in West Africa changed in response to the European scramble for African colonies; the British Government revoked the charter of the Company, and declared a protectorate over Northern Nigeria, beginning $1^{\text {st }}$ January 1900.

The protectorate administration aspired to colonial development, seeking to promote economic development in Northern Nigeria for the mutual benefit of the local people and their British rulers, although this objective would quickly change to economic exploitation for the colonial state. In order to realise its objective, however, the new administration had to establish authority over the local polities and organise effective government. By 1906, the entire region had been subdued; the protectorate was divided into provinces, and a system of administration established.

Protectorate administration, developing on the Company practice, was essentially indigenous, involving the adoption of local political structures. Essentially, the protectorate administration was a two-tiered system. The upper tier comprised a hierarchy of colonial rulers or Colonial Civil Service, which was responsible for the central administration of the protectorate. The civil service was organised into several departments, of which the political department was the pivot of government.

The political department was composed of expatriate governing officials, such as the high commissioner and his private secretary; the secretary to the administration; political officers or residents and their assistants; indigenous service assistants, such as clerks and political agents. The residents served as senior government officials and representatives of the high commissioner in provincial administration; they were assisted by district officers in the various divisions of the provinces. Among their major functions, residents and district officers conveyed all government orders to the provincial functionaries; they also supervised 'Native Administration' or the indigenous hierarchy which formed the subordinate tier in the protectorate government.

The subordinate administration was modelled on the emirate system of local government prevailing in the region, and it evolved over the years. Essentially, it was composed of the indigenous ruling elite; emir, his councilors and district heads administering the various districts. Below them were village heads placed in charge of villages in the districts. Traditional courts existed at the various levels of government. There, traditional law and customs were administered and government proclamations enforced. A provincial 
court existed at the capital of each province. Headed by the resident, it handled cases outside traditional jurisdiction.

Political activity in the protectorate administration was largely informed by patronclient relations. Interaction between the two hierarchies of government involved brokerage of colonial authority, and that required political agents. They were hard to find, largely because of the financial cost involved as well as the stringent requirements for their employment, including personal resourcefulness, geographical knowledge of the territory and linguistic ability, in particular. ${ }^{2}$

Agents in the protectorate régime had to demonstrate good language skills. In fact, the protectorate government, unlike its predecessor, developed a language policy for its agents. This is not surprising considering that agents were needed for a greater variety of tasks than hitherto. The language skills involved fluency and literacy in Standard English; proficiency in Hausa, a lingua franca of the region; and knowledge of other indigenous languages, such as Kanuri in Borno, or Yoruba in Ilorin. ${ }^{3}$

The language requirement was used by the colonial officials as the basis for the recruitment and classification of agents. Accordingly, candidates were tested in language examinations and graded into three classes. ${ }^{4}$ The examination in English was classified into lower and higher standards. The lower standard test was an oral examination that involved conversations in Standard English between a candidate and an examining board, composed of British colonial officials. Each candidate was expected to engage in 'six different conversations as far as possible with different Europeans each on different subjects, lasting about 10 minutes. ${ }^{5}$ In order to pass the lower standard test, a candidate was expected to demonstrate clearly, an understanding of the examiners' statements, and earn a grade of forty per cent.

A candidate needed a grade of eighty per cent to pass the higher standard examination. Such a candidate was expected to be fluent in English, with good pronunciation and knowledge of a fairly large vocabulary. In addition, the candidate was required to read English in manuscript and in print. The candidate was further obliged to 'write accurately from dictation and compose a fairly grammatical and intelligible letter. ${ }^{6}$

Agents' proficiency in the indigenous languages was also assessed. Candidates were examined orally by one or more of the best agents in the presence of the examining board

2 SNP 1/1 4 (238/1904) High Commissioner, Northern Nigeria, to Secretary of State, Zungeru, 26 January 1904; also (Afeadie, 2008, pp.43-50).

$3 \quad$ SNP $742 / 1902$ Examinations in English, enclosed in Language Gratuities; SNP 1/1 vol.4 High Commissioner to Secretary of State. (N.N.40 238/1904)

$4 \quad \mathrm{CO} 446 / 6$ p.609. Colonel Lugard to Colonial Office (Received, 11 May 1899), Civil Establishments Estimates for 1900-1901.

$5 \quad$ SNP 7 42/1902 Language Gratuities.

6 SNP 7 42/1902 Language Gratuities.

Legon Journal of the Humanities 26 (2015) 
that awarded the marks. Many candidates, particularly personal attendants of political officers, were initially engaged without the language test. However, in 1902 Lugard demanded that those candidates should present themselves for examination and if successful, be given a certificate showing the number of marks obtained. This certificate would largely determine their chances of promotion and increase of pay.

Agents who obtained high grades in the language examinations belonged to the firstclass division. As the high commissioner directed in 1902, any candidate "who can pass the Higher Standard in English and who can also read and write Arabic letters will rank in the first grade. ${ }^{7}$ Arabic literacy for political agents was essential because the language was the means of correspondence for the predominantly Muslim rulers of the region.

A few agents were, indeed, proficient in English. Kiari and J.K. Davies were literate in English and Arabic, besides being competent in Hausa and other local languages; they therefore qualified for the position of first-class political agents. Kiari was Lugard's best political agent. Born in Borno, Kiari was Kanuri in ethnic origin and language, and proficient in Fulfude, a Fulani language. ${ }^{8}$ J.K. Davies, originally a malam and trader was also fluent in Yoruba and Nupe, his father being a West Indian freed slave, and the mother, Yoruba. ${ }^{9}$ Agent Yusuf, of Nupe ethnicity, was 'a man of great presence, extremely capable, and [possessed] a good command of English. A great knowledge of History, Geography, local politics. ${ }^{10}$ He also spoke Yoruba, Nupeand Hausa.

Agents who passed the lower standard examinations belonged to the second-class division. They possessed a passable knowledge of Standard English, and some of them were literate in Arabic, as well. All of them were presumably proficient in Hausa and other native tongues. Momo Lafia, who served in Kontagora province in 1906, spoke English 'fairly, and also Nupe and Hausa, Yoruba and Kakunda.' ${ }^{11}$ Abaji Gidda, a veteran agent in Borno

7 SNP 7 42/1902 G.M. Moloney, Resident Lower Benue, to the Secretary to the Government, Lokko, 27 January 1902, Language Gratuities.

8 CO 446/30 (no.15493) p.669.Lugard to the Secretary of State (Confidential despatch), Kano, 7 March 1903, Kano Expeditionary Force; SNP 7 1355/1906 Lugard, Lokoja, May 16, 1906, Approved Political Native Staff, Sokoto Province, 1906-7.

$9 \quad$ NAK/O/ARLI/vol.III/204 Abadie to High Commissioner in Jebba, Wushishi, 13 May 1902; also (Staudinger, 1992, pp.32, 39).

10 Arewa House Archives, Kaduna (AHAK) Confidential Reports on Chiefs, Ilorin, Acting Resident Hermon Hodge, 21 January 1921.

11 SNP $7 / 7$ 1351/1906 (no.512/06) Resident Kontagora, W.S. Sharpe, to the High Commissioner, Northern Nigeria, enclosed in Approved Political Native Staff, Kontagora Province, 19061907. 
province, also spoke English quite well. In addition, he was literate in Arabic and fluent in Fulfude, Hausa and Kanuri. ${ }^{12}$

Many good agents and would-be agents ranked in the third class, because they barely knew Standard English. ${ }^{13}$ As High Commissioner, Lugard lamented in 1904, 'sufficient interpreters do not exist to supply each of these [Political] Officers with one; such as obtainable are almost without exception exceedingly bad, and do not understand sufficient English to grasp the meaning of even a simple sentence. ${ }^{14}$ Despite their imperfect knowledge of Standard English, third-class agents could still work effectively because they, as well as their senior colleagues, were proficient pidgin. For the colonial officials, just as their Company counterparts, pidgin was convenient as a working language of government. Temple (1968), a former resident and lieutenant-governor of Northern Nigeria, aptly observed that "in West Africa "pidgin English" is a language that has to be acquired. It is not "broken" English. And it is a capital asset for a British officer who wishes to be certain of not being misunderstood' by agents (p.246).

The pidgin jargon included such elements as 'daddy' (father), 'mammy' (woman), 'pikkin' (son, boy), 'yabash' (onion), 'savve' (to know), 'he no fit' (cannot, he is not able to), 'he pass, pass all' (he is better than, he excels), 'all my skin hot me' (I am hot, I have a temperature), 'You savve God?' (Are you Christian?) [Staudinger, 1992, vol. I, p.84]. Other elements are 'kuku boy' (steward), 'kuku meti' (cook meat), 'ruge' (rogue), 'parashi' (price) [Interview, Alhaji Garba Saidu, Kano, 22 June 1993].

George Hazzledine (1904), who was for some time Private Secretary to High Commissioner Lugard, relates the language of a government interpreter, Musa, who was remonstrating a domestic servant; Musa heard the boy complaining about being whipped for stealing "“a tin of lard holding forth... on the cruelty of the White Man...," Musa, "catching the fat youth by the ear, said: "You be one big fool, you! If de White Man no come, you be slave and carry brick for de Fulani all day. You no savvy dat? You be one big fool!"' (p.83).

\section{Mediatory Tasks of Governance}

Equipped with pidgin and other resources, political agents performed a variety of tasks in colonial governance, with many of the duties overlapping, the major ones being

12 Interview, AlhajiGarbaMuhammaduSaidu, 23 June 1993, Kano; SNP 15 Acc.19 Hewby, Report no.3 of 28 February 1903, enclosed in Bornu Reports, 1902-1903.

13 As of 1928 only a few people were receiving education in English in Nigeria, some 100,000 out of a population of over 20 million. Relating to that, only 10,000 out of over 10 million people were receiving education in English in Northern Nigeria. This condition did not change much until World War II (Spencer, 1971, pp.21-22).

14 SNP 1/1 4 (238/1904) High Commissioner, Northern Nigeria, to Secretary of State, Zungeru, 26 January 1904. 
the conduct of government diplomacy, intelligence gathering and administrative tasks. Diplomacy was crucial to British policy in Northern Nigeria and political agents were essential to colonial diplomacy, by reason of their knowledge of local culture and languages of communication, primarily pidgin. Throughout the Company régime and the early years of the Protectorate administration, political agents were the ones largely responsible for establishing and managing government relations with traditional rulers. Agents dominated the process of negotiating and maintaining political and commercial treaties with the indigenous ruling elites, and agents interpreted and transmitted messages between colonial officers and enemy troops on the battlefield, parleying with the enemy troops for peaceful solution to their problems. ${ }^{15}$ Conduct of government diplomacy was a difficult task for political agents, because many of the chiefs resented colonial rule. Nevertheless, many agents performed effective service and helped to secure peace in the region.

Intelligence gathering was a major duty of political agents in colonial administration. Agents produced intelligence in both peace and war times. In civil intelligence, agents were initially preoccupied with gathering information on the structure of the local politics, because the colonial authorities needed such information to determine basic policy objectives in the region (Heussler, 1968, p.30; Lugard, 1965, p. 140, p. 195). In wartime, political agents informed the colonial authorities about the military resources of the local rulers and on public opinion. Agents were particularly effective in intelligence gathering during the planning and operation of the Kano-Sokoto campaign of 1903.Six outstanding agents served in the British conquest of Kano; Ibrahim, Mainasara, Kiari, Maimaina, Auta and Adamu Jakada all participated in the battle of Kotor kwashi, and Captain George Abadie would commend Ibrahim for his part in tracking down the fugitive Emir Aliyu during the campaign. As Abadie noted:

My best spy, and the only one I can trust, whom I had sent on the 5th [of February 1903] to ascertain where Alieu and his party were staying and also what had happened to the people who ran from Kano when we entered, returned and has given me the following and apparently reliable information. Alieu is at Magamma M'Didi and the rest of his brothers and his sons are dotted about in small towns all round. He has a screen of mounted men on the W. edge of the large tract of bush (about Kurrofi) ... The whole of the people who ran from here and the headmen of the towns above mentioned with their horsemen are collected at SAURI which is just across the Kano-Katsina boundary and

15 NAK/SNP 6/3 95/1907 Instructions for the control of Expeditions, Patrols and Escorts. (Based uponResidents Proclamation 1900; G.S.O. 1, sections 18, 88, 89; Political Memo 7; W.A.F.F. Regulations 103 to 109 ). 
about 4 miles $\mathrm{N}$ of the place marked DURU on the old Intelligence map. There are at this place some 1000 to 1500 horsemen and I am of opinion that from all I can hear, if this large force is dispersed, Alieu's party will also disperse when they hear news of it. ${ }^{16}$

Not only did agents conduct local intelligence operations, they also spied for the colonial government in foreign territories adjoining the protectorate. Such agents provided their superiors with information, especially on political unrest, military resources and activities of the occupying colonial powers as well as on geographical features (Lugard, 1965, p.33). Predictably, there were many double agents, as some agents gathered information simultaneously for the colonial government and the indigenous ruling elite.

Political agents usually conveyed information to their employers orally and largely through pidgin, but some agents transmitted information in writing, through Arabic and Hausa. ${ }^{17}$ And there was the rare record of written pidgin, involving the letter of Agent Audu Momo, which Resident David Carnegie enclosed in a correspondence with his sister in England in August 1900 (O'Hear, 1992, pp.112-113).Information transmitted by agents, either in writing or by word of mouth, was not always accurate, however. It occasionally suffered distortion and deficiency (Afeadie, 2008, p. 90).

However, colonial authorities were not always deceived by the inaccurate information transmitted by some agents, because they possessed several means of processing data. In one method, as Temple (1968) notes, political officers who spoke some indigenous languages avoided excessive reliance on their pidgin-speaking agents by sending informal agents who were non-pidgin speakers together with the pidgin-speaking agents on each assignment (p.246). By this means, the political officers obtained adequate data to sift through, the data differing according to the investigators and in the language of transmission. On some occasions, political officers who spoke the indigenous languages worked quite independently of agents. They consulted with traditional authorities and the ordinary people, and picked up information to verify the credibility of agents' reports.

The methods, however, had their drawbacks, as the colonial authorities often suffered a shortage of political agents. Besides, only a few political officers spoke Hausa or other indigenous languages, and they could hardly afford enough time from their onerous duties. When they did so, they could consult with only a few people because they inspired fear and resentment in the general populace. Thus, information produced by agents could not be purged of all inaccuracies.

16 SNP 17/2 (16976), pp.11-12. From the Resident, Kano Province, to the High Commissioner (Kano 1/1903), 12 February 1903, Historical Documents on the Capture of Kano.

17 Interviews, AlhajiGarbaMuhammduSaidu, Kano, 22 June 1993; Alkali Alhaji Ali Waziri, Kano, 6 July 1993; also (Temple, 1968, pp.40-41). 
In addition to their diplomatic and intelligence duties, political agents, proficient in pidgin, performed administrative functions in Northern Nigeria, which functions evolved over time. Initially, agents served as administrative auxiliaries to the political officers, as they managed Company's trading stores and enforced commercial regulations. ${ }^{18}$ Upon the establishment of the protectorate administration, agents were deployed into the political education of the people, an aspect of colonial pacification. As administrative auxiliaries, agents also waited on political officers; they received visitors, both indigenous administrative officials (hakimai) and ordinary people (talakawa), and handled their transactions with the political officers. ${ }^{19}$ In another capacity, agents served as messengers and ran messages between political officers and indigenous ruling officials. Typically, pidgin featured prominently in the mediation process. For instance, East (1965) relates that agents who served among the Tiv people delivered and, in addition, interpreted messages between the political officers and the staff-chiefs, the latter of whom spoke neither Hausa nor English and therefore, needed translators and interpreters (p.392).

In the period 1906-14, many political agents were directly engaged in administration as opposed to their previous role as mere auxiliaries. This development reflected the change in colonial policy, as the period witnessed the consolidation of colonial conquest, characterised by the development of provincial administration and effective government. Many agents were appointed to positions in the indigenous administration in the interests of the colonial authorities. As Afeadie (2008) points out, the agents participated in local government and served in varying capacities; as district head; as treasurer, supervising financial administration of community native treasury (beit-el-mal); and as district judge (alkali), assisting the administration of justice (pp.105-117). All these were crucial domains of colonial governance.

\section{Derivative Power of Pidgin}

Political agents occupied a crucial position in Northern Nigeria, primarily by their command of language and their intermediary role in administration. Owing to their position, agents commanded political influence and occupied a high status in society. Inevitably, agents had influence with the traditional authorities and the people. A complainant or visiting official could not meet a political officer without passing through a political agent. As to the

18 These involved collection of export and import duties from foreign traders, administration of trade licenses, and the adjudication of local disputes brought before the Company's courts (Flint, 1960, pp.92-98, and 144-146; Pedler, 1974, pp.125-128).

19 Interview, Abdulkadir, MajaSirdin Kano, Kano, 17 August 1993. According to the informant, hakimai (officials of the indigenous administration) or talakawa (ordinary people) who wanted to see a political officer had to go through agents like Tanko. A similar statement was made by another informant, MallamBasikuJibrinZarewa but he referred to AdamuJakada to exemplify the agents. (Kano, 18 July 1993). 
traditional rulers including emirs (sarakuna), Afeadie (2008) notes that a political agent could be sent to collect an emir's staff of office, in the event of the emir's misconduct (p.118).

In consequence, the friendship of agents was cultivated by the traditional authorities. Many agents were known to receive gifts, such as expensive gowns and horses from the indigenous ruling officials; they also had marriages arranged and financed for them by the officials. ${ }^{20}$ According to Kano traditions, some agents who were Muslim often participated in private prayers with some indigenous rulers during off-hours while some of the indigenous elite were known to pay home visits to some political agents. On the other hand, agents had influence with the political officers; run-away slaves sought refuge with political agents, and political officers entrusted in some agents the guardianship of the freed slaves. ${ }^{21}$ Given these cases of entrustment, agents exploited their influence for several purposes. They could have people arrested for offences on their own authority (Afeadie, 2008, p.121). Some of them engaged in extortion, manipulating the people's fear of being reported or misrepresented to the colonial authorities for real or supposed offences. ${ }^{22}$ Also, many agents would misinform political officers who relied on them because of their limited knowledge of the indigenous languages. Resident Temple (1968) characterised a political officer in such a situation as a "domestic slave" to his agent (p.246).

Not surprisingly, a political agent was held in awe by the general populace, because of his influence and how he exploited it. The traditional authorities held the British conquerors in high regard; accordingly, they dreaded political agents because they worked closely with the colonial authorities, and they could poison relations between the colonial officials and the chiefs. ${ }^{23}$ District Officer, Arthur T. Weatherhead, is noted as having observed that "no one in Nigeria understood the British so well as the messengers, "the eyes and ears"" of a political officer (Heussler, 1968, p.118). For their part, the people (talakawa) considered their British conquerors to be as powerful as their traditional rulers. As Emir Abbas informed a British journalist, E.D. Morel, in 1912, 'all white men are "sarikis" (chiefs) and the people cannot help so regarding them' (Morel, 1912/1968, p.134). As officials who communicated directly with the colonial authorities and who mediated between them and the indigenous rulers, political agents were regarded by the people as powerful in their own right.

20 Interviews, AlhajiGarbaMohammaduSaidu, Kano, 22 June 1993; AlhajiInuwa Wada, Kano, 29 June 1993.

$21 \quad$ Northern Nigeria Gazette, no.19, 1900, p. 131. Quarterly List of Liberated Slaves Registered 15 March to 30 March 1900; Northern Nigeria Gazette, August 1901, p.112.

22 Annual Reports, Northern Nigeria, 1900-1912, p.268. Also, Resident Temple aptly observed that 'the extraordinary impertinence of which a sophisticated native can be capable, the preposterous requests which he can make in his master's name must be actually experienced before they can be believed' (1968, p.126).

23 Interview, MallamDa'u, Kano, 13 July 1993.

Legon Journal of the Humanities 26 (2015) 


\section{Controlling Communicative Power}

Political agents were generally distrusted by their employers, because of the illegitimate ways they used their influence. But there were other reasons as well. Government resentment of some agents was based on a misunderstanding of their conduct, as some agents subscribed to the ideology of pretended cooperation with the colonial regime; and also, government distrust of agents arose from racial prejudice. ${ }^{24}$

Naturally, agents were subject to control in the colonial administration, especially when they used their political influence in illegitimate ways. One important means of control was the Protection of Natives Proclamation, enacted in 1901 to deal with impersonation of government officials and amended in 1903 to include the acceptance of bribes and presents. ${ }^{25}$ Such offences were punishable by imprisonment, fines and flogging. Under the proclamation, the penalty for receiving bribes or improper presents was imprisonment with hard labour for six months or a fine or both. ${ }^{26}$ As to flogging, the amended act authorised court officials to administer a minimum of 36 lashes to culprits immediately on conviction and sentencing. This was intended to provide moral effect on the convicts and on the court. Other agents could be demoted or dismissed, on conviction. In converse to punishing agents for their misconduct, colonial officials encouraged good behaviour in their trusty agents. Such persons were rewarded with increased salaries, gifts, special benefits or medals of honour.

Although reliable political agents existed in the colonial administration, they were few in number. Moreover, agents could not be adequately controlled through the existing system of reward and punishment. In the prevailing conditions of agents' scarcity, the ineffective control system manifested in the re-employment of some agents who had been dismissed for offences against the colonial government (Afeadie, 2008, p.135). In view of the limitations in their control system, the colonial authorities sought other means to reduce the intermediary role of agents and restrict their influence. To this end, they instituted a policy of language training for political officers in a bid to promote direct communication between them and the people.

The general objective of the language policy was to deprive political agents of the power derived from pidgin and Arabic, which were working languages of government. Agents enjoyed speaking pidgin with the confident sense of African ownership, because it

24 Afeadie, 2008, p. 39. Also, during the colonial period expatriate officials held to a body of subjective opinions about the African people (Cohen, 1970, pp.427-431). According to Alan Burns (1948), a former governor of Nigeria, 'colour prejudice is present, even when not consciously felt, in the relations of white traders, teachers, missionaries and officials, to the coloured inhabitants.' (p.12)

25 SNP 1/1 3 (no.44) High Commissioner to the Secretary of State for Colonies, Zungeru, 30 January 1903, Protection of Natives (Amendment) Proclamation 1903.

26 Northern Nigeria Gazette, February 1904, pp.11-12.

Legon Journal of the Humanities 26 (2015) 
served them very well. Political officers, for their part, were not comfortable with pidgin, as they resented agents' control and abuse of the language. Thus, political officers sought a language of administration that would accord them direct contact with the traditional authorities and the people. They chose Hausa and consequently compelled all political officers to learn it. Resident Temple (1968) advised:

It is extremely improbable that a political officer will not find in any village of the Northern Provinces of Nigeria a man who does understand Hausa enough to interpret. Even if he cannot find a man of that village it is easier for him to find some native who understands the language spoken in that village and Haussa as well, than to find anybody who understands that language and even the most elementary 'pidgin' English. So that an officer if he knows Haussa is at all events likely to be independent of his own 'English' speaking interpreter, instead of being his 'domestic slave'; he will at all events have a choice of interpreters, and be able to use first one and then another, so that the villagers may see that he is capable of exerting his free-will in some respects, and is not entirely at the beck and call of one 'tarprinta' [the pidgin term for 'interpreter.']. (p.246)

Thus, knowledge of Hausa in particular, and any other language (Yoruba, Nupe, Kanuri, Bassa or Okpoto) which was widely spoken in the territory of a political officer, became requirements for promotion. ${ }^{27}$ Accordingly, language examinations were conducted for interested candidates, the Hausa Language Examination being predominant. Revealingly, political officers were entitled to language gratuities ranging from $£ 15$ and $£ 30$, on the successful completion of the Hausa Language Examination. ${ }^{28}$

To reduce the role of agents, the language policy also sought replacing Arabic with Hausa as the official language of correspondence for the people, especially the indigenous ruling elite. Prior to the advent of colonial rule, Arabic was the medium of correspondence in the region. Arabic scholarship exploded with the spread of Islamic education, in the wake of the jihad of Uthmandan Fodio, launched in 1804. The teachers who were known as malamai acquired competence in Arabic after years of training, which began in youth. Thus Arabic scribes abounded in the region, and many of them, indeed, served as agents in the

27 SNP 7 42/1902 G.M. Moloney, Resident Lower Benue, to the Secretary to the Government, Loko, 27 January 1902, Haussa Language Examinations (188/1902), enclosed in Language Gratuities; SNP $1 / 14$ (238/1904) High Commissioner, Northern Nigeria, to Secretary of State, Zungeru, 26 January 1904.

28 SNP 7 42/1902 Haussa Language Examinations (188/1902), and Examinations in English, enclosed in Language Gratuities. 
colonial administration. Agents Sani and Jafaru, for instance, were Arabic scholars. ${ }^{29}$ Many of the scribes, however, lacked literacy in English and could not conduct direct correspondence between the colonial officials and the traditional authorities. Conversely, the colonial authorities were largely reluctant to promote literacy in Arabic among the colonial officials. ${ }^{30}$ Meanwhile, Christian missionaries had been promoting writing in Hausa by encouraging the development of ajami, Hausa written in Arabic characters. ${ }^{31}$ But Lugard objected to the spread of ajami which he described as 'spurious Arabic' and unintelligible to political officers. Instead, he wanted to introduce Hausa in Roman characters, the new script considered more suitable in expressing Hausa sounds, and readable by political officers (Graham, 1966, p.27). Accordingly, a school was established at Bida for the training of students in the new script.

In Lugard's estimation, the language policy for political officers was progressive, as those who passed the examinations made use of their language skills to control agents. Thus Lugard noted in 1904:

It was owing to Dr. Cargill's knowledge of Hausa that he was able to detect a widespread scheme of extortion and slave dealing in the Muri province, carried on in the name of Government by the Interpreter [IssaKada]. Later he discovered that it had been due to malpractices and misrepresentation on the part of Captain Moloney's interpreter [Abdu Tintin] which had led to that officer's sad death, and lately Mr. Webster, who had acquired a fair knowledge of Hausa, was able thereby to avert a needless war and convict the real culprit. ${ }^{32}$

In fact, political officers who knew the indigenous languages were few in numbers. ${ }^{33}$ In effect, their achievements were of little avail to the control of the relatively predominant political agents and their instrument of pidgin. Besides, the indigenous people did not readily adopt the Roman script in writing Hausa. For their part, indigenous rulers continued to write official letters in Arabic, reflecting the resilience of cultural tradition. As such, the colonial

AHAK H. Hale Middleton, D.O.ii, 31 December 1917, Native Staff Confidential Report, Kano, 1917; AHAK Resident Gowers, Native Staff Confidential Report, Kano, 1918.

30 Christian missionaries and colonial officials in northern Nigeria were known to detest Islam and Arabic influence in the region, owing to the colonial experience with the jihad movements in India, as well as Urabi Pasha's revolt in Egypt and the Mahdist rising in the Sudan (Robinson, 1999, p.405; Ayandele, 1966, p.126)

$31 \quad$ SNP 7 42/1902 Language Gratuities.

32 Annual Reports, Northern Nigeria, 1900-1912, pp.215-216.

33 They included G.W. Webster, W.F. Gowers, H.R. Palmer, C.L. Temple, E.J. Arnett, W.S. Sharpe and H.H. Hermon-Hodge (Heussler, 1968, pp.123-126; Kirk-Greene, 1988, p.6; Graham, 1966, p.36) 
authorities continued to recruit Arabic scholars into the colonial service, and interested political agents were allowed to sit language examinations involving the study of Arabic. Obviously, the language policy was failing. Political agents, therefore, remained crucial to colonial administration.

Colonial authorities, nevertheless, continued to dislike the influence of pidgin and the position of political agent, and accordingly sought the abolition of the post in subsequent years. In the 1920s, as Heussler notes, 'Kaduna first issued a directive against the use of informers and then abolished Political Agents; but not before a certain amount of harm had been done in preventing more direct communication between D.O.s and N.A.s [District Officers and Native Authorities].' (1968, p.119). In practice, colonial officials could not abolish the post of political agents in its entirety; they merely changed their title to 'messenger', as their service remained indispensable and valuable. According to McClintock (1992), the 'messengers' who supposedly replaced political agents possessed the same characteristics and identity as the political agents, and they performed similar duties and wielded influence as political agents (p.16).

Of the language policy, it was well on the decline, as political officers who sat the examination were very few, and the numbers continued to dwindle over the years, in spite of incentives. By 1962 the policy had become redundant. With the spread of Standard English, and the Africanisation of the public service underway, the demand for expatriate political officers and their need to learn the local languages largely diminished (Kirk-Greene, 1988, p.10). The commanding influence of pidgin had also waned with the ending of colonial rule.

\section{Pidgin Today}

In the post-colonial period, pidgin would serve a complementary role to burgeoning Standard English and indigenous Nigerian languages. In that regard, pidgin would expand its function as lingua franca, serving Nigerians, especially southerners in many important contexts. As Mafeni (1971) notes, the condition of multilingual family settings in many urban areas of Nigerian enabled the adoption of pidgin as a major medium of communication for husbands and wives and children at home (pp.98-99). Further, at primary and secondary schools among immigrant communities in Northern Nigeria as well as cities of multilingual populations in southern Nigeria, pidgin was the primary means of communication in school compounds and outside the classroom. Similarly, pidgin served as a convenient lingua franca among uneducated people in multilingual working contexts.

In the Niger Delta region of Benin City, Calabar, Port Harcourt and Warri, Aziza (2006) observes,

the Nigerian Pidgin (NP) is virtually indispensable in its communicative function in the home, school, church, market place, office - in fact, for most 
interpersonal communicative needs, including inter and intra-ethnic communication. It eases the language barrier that the many languages in the area would have created. In the mass media NP is extensively used in the radio and television for both entertainment and educational purposes. ${ }^{34}$ Adverts are common in the language and even government announcements are regularly relayed in NP for a wider reach. There are also pidgin columns in a number of periodicals. (pp.184-185)

The army and police would also adopt pidgin as a language of wide communication and instruction in the junior ranks, noted Achebe (1987, pp.191-194) This practice developed from the establishment of the West India Regiments in Sierra Leone in the first half of the $19^{\text {th }}$ century, through the operation of the British colonial army, the West African Frontier Force (WAFF), where pidgin and Hausa were spoken among the soldiers. As with other West Africans today, pidgin is intelligible to educated Nigerians, including university lecturers and government officials, but they would rather speak the language in informal settings such as entertainment spots and among friends. Predictably, pidgin prevails at the workplace, particularly among urban dwellers in West Africa.

\section{Conclusion}

Pidgin in West Africa emerged as a language of trade, a medium of communication between Africans and European traders. Soon, pidgin developed as a lingua franca between the multi-ethnic groups on the West African seaboard. In the absence of a wider means of inter-ethnic communication at the workplace, the British authorities adopted pidgin as a working language of colonial government in Northern Nigeria. This enabled African employees who spoke pidgin to perform important tasks in governance, and thereby acquired political influence, which they often abused, thus challenging British colonial hegemony in Northern Nigeria. As a result, colonial authorities resented that influence, but they could not effectively control it. The status and influence of political agents would only diminish in the twilight years of colonial rule, with the spread of English language as a wider medium of inter-ethnic communication.

Today, pidgin has developed as a major lingua franca in multilingual settings such as homes, schools and working places in many urban areas of Anglophone West Africa, particularly in Nigeria. Pidgin is widely spoken, not just among people lacking proficiency in Standard English but also among formally educated Anglophone West Africans. As such, pidgin facilitates the vertical and horizontal communication process.

Novelists, playwrights and musicians also communicated to their audiences in pidgin. 
Remarkably, pidgin has retained its unique characteristic and usefulness as a language of the workplace in West Africa today, albeit suffering from the colonial legacy of resentment in the ambivalent attitudes of the elite in post-colonial contemporary Africa. 


\section{References}

Achebe, C. (1987). Anthills of the savannah. London, UK: Heinemann.

Afeadie, P. A. (2008). Brokering colonial rule: Political agents in Northern Nigeria, 1886-1914. Saarbrucken, Germany: Verlag Dr. Muller.

Ayandele, E. A. (1966). The missionary impact on modern Nigeria 1842-1914. London, UK: Longmans.

Aziza, R. O. (2006). The pidgin factor in the development of the Niger Delta Region of Nigeria. In E. N. Chia(Ed.), African linguistics and the development of African communities (pp.184-190). Dakar, Senegal: CODESRIA.

Burns, A. (1948). Colour prejudice. London, UK: G. Allen and Unwin.

Cohen, W. B. (1970). The colonized as child: British and French colonial rule in Africa. International Journal of African Historical Studies, 3(2), 427-431.

Dantzig, A. V. (1978). The Dutch and the Guinea Coast, 1647-1742: A collection of documents from the General State Archive at The Hague. Accra: Ghana Academy of Arts and Science.

Dantzig, A.V. (1999). Forts and castles of Ghana. Accra, Ghana: Sedco Publishing Limited.

East, R. (1965). Akiga's story. London, UK: Oxford University Press.

Flint, J. E. (1960). Sir George Goldie and the making of Nigeria. London, UK: Oxford University Press.

Fremantle, J. M. (1925). Gazetteer of Muri province. London, UK: Waterlow.

Graham, S. F. (1966). Government and mission education in Northern Nigeria 1900-1919. Ibadan, Nigeria: Ibadan University Press.

Hazzledine, G. D. (1904). The white man in Nigeria. New York, NY: Negroe Universities Press.

Heussler, R. (1968). The British in Northern Nigeria. London, UK: Oxford University Press.

Huber, M. (1999). Ghanaian pidgin English in its West African context. Amsterdam, Netherlands: John Benjamin's Publishing Company.

Kirk-Greene, A. H. M., \& Newman, P. (1971). West African travels and adventures. Two autobiographical narratives from Northern Nigeria. New Haven, CT: Yale University Press.

Kirk-Greene, A.H.M. (1988). Examinees, examiners and examinations: The Hausa language requirements of the Northern Nigerian Government, 1902-1962. In G. Furniss \& P.J. Jaggar (Eds.), Studies in Hausa Language and Linguistics. London, UK: Kegan Paul.

Long, D. (2007). English on the Bonin (Ogasarawa) Islands. Durham, NC: Duke University Press. 
Lugard, L. (1965). The dual mandate in British tropical Africa. London, UK: Archon Books.

Mafeni, B. (1971). Nigerian pidgin. In John Spencer (Ed.), The English language in West Africa (pp.95-112). London, UK: Longman.

McClintock, N.C. (1992). Kingdoms in the sand and sun. London, UK: Radcliffe Press. Mockler-Ferryman, A.F. (1892). Up the Niger. London, UK: G. Philip \& Son.

Morel, E. D. (1912/1968). Nigeria: Its peoples and its problems. London, UK: F. Cass.

Norregard, G. (1966). Danish settlements in West Africa 1658-1850. Boston, MA: Boston University Press.

O'Hear, A. (1992). Letters from Nigeria 1899-1900. David Wynford Carnegie. Madison WC: University of Wisconsin Press.

Pedler, F. (1974). The lion and the unicorn in Africa: A history of the origins of the United African Company 1787-1931. London, UK: Heinemann Educational.

Perham, M., \& Bull, M. (1963). The diaries of Lord Lugard, IV. Evanston, IL: North western University Press.

Robinson, F. (1999). The British Empire and the Muslim world. In J. M. Brown \&R. W. Louis (Eds.), Oxford history of British Empire, vol. IV (pp.398-419). Oxford, UK: Oxford University Press.

Spencer, J. (1971). West Africa and the English language. In J. Spencer(Ed.), The English language in West Africa (pp.1-34). London, UK: Longman.

Staudinger, P. (1992). In the heart of the Hausa states, 2 vols. Athens, OH: Ohio University Center for International Studies.

Temple, C. L. (1968). Native races and their rulers. London, UK: Cass.

Submitted: March 15, 2015 / Published: May 30, 2016 